\title{
Labneh with probiotic properties produced from kefir: development and sensory evaluation
}

\author{
Daniela Mayumi Usuda Prado ROCHA ${ }^{1 *}$, Joice de Fátima Laureano MARTINS², \\ Thanise Sabrina Souza SANTOS ${ }^{1}$, Ana Vládia Bandeira MOREIRA ${ }^{1}$
}

\begin{abstract}
The labneh or labaneh is a popular fermented milk in the Middle East. Another fermented product that deserves special mention is kefir since it has probiotic activity and unique sensory, nutritional, and therapeutic properties. The aim of the present study was to develop a functional probiotic labneh using kefir as a fermenting agent and to perform a sensory analysis of the obtained product. Kefir was obtained by growing grains in pasteurized milk. Samples of skimmed and whole labneh were prepared from the inoculation of $5 \%$ kefir milk (skimmed/whole) at $28^{\circ} \mathrm{C}$ for $24 \mathrm{~h}$, followed by cooling (12-18h) and whey drainage (12-24h), both at $4{ }^{\circ} \mathrm{C}$. Sensory analysis was performed with 70 untrained panelists using a 9-point scale hedonic in the acceptance tests. The paired t-test was used to compare the differences between the means of the scores obtained, with the significance level of $5 \%$. The labneh prepared showed good acceptance by the judges, and the whole labneh samples had the highest scores in the acceptance test. Further studies on the analysis of microbiological viability, nutritional composition, and determination of shelf life, also to improve acceptability of the low-fat version of the product, are needed.
\end{abstract}

Keywords: strained kefir; Greek yogurt; fermented milk; functional foods; taste; texture.

\section{Introduction}

\subsection{Labneh}

Labaneh or labneh (concentrated yogurt) is a popular fermented milk product in the Middle East, which has a significant role in family nutrition (Abd El-Salam et al., 2011). It is also known as skyr (Iceland), shrikhand (India), and Greek yogurt (Greece and other countries) (Ramos et al., 2009).

Labneh has a cream or white color, a soft and smooth body, good spreadability with little syneresis, a clean flavor, and slight acidity (Nsabimana et al., 2005). It is considered an intermediate product between fermented milks and immature cheeses with high water content, such as quark, boursin, and petit suisse, with physical characteristics similar to those of these products due to the syneresis process (Ramos et al., 2009).

Nutritional and therapeutic properties of labneh are considered similar to or even better than those of yogurt. Labneh has 2.5 times higher protein content, $50 \%$ more minerals, and a considerably larger number of viable microorganisms than common yoghurt (Nsabimana et al., 2005). In addition, the lactose concentration of labneh is low (approximately 6\%) due to its fermentation into lactic acid, which makes it more suitable for use by lactose intolerant individuals (Nsabimana et al., 2005; Özer \& Robinson, 1999).

Due to its high total solids content, labneh may be considered a suitable matrix for probiotics since it offers protection when added to them (Abd El-Salam et al., 2011).

\subsection{Probiotics}

The term probiotic is used to designate live microorganisms, which when administered in adequate amounts, exert positive influences on the host's health (Guarner et al., 2012). The beneficial effects of probiotic use on health are associated with the maintenance of a healthy intestinal microbiota by its regular consumption (Yerlikaya, 2014).

When used in foods, probiotic organisms must be able to survive passage in the gastrointestinal tract, resisting the action of the gastric juice and bile exposure. They are then able to proliferate and colonize the digestive tract to display their beneficial effects. Moreover, probiotics should be safe and effective, and also maintain their effectiveness during the shelf life of the product (Food and Agriculture Organization of the United Nations \& World Health Organization, 2006).

The main mechanisms of action of probiotics include: an improved intestinal mucosal barrier (Persborn et al., 2013; Zeng et al., 2008); increased adhesion to the intestinal lumen interface and concomitant inhibition of the adhesion of pathogens (Balgir et al., 2013; Lara-Villoslada et al., 2007); competition with pathogenic microorganisms for binding sites, nutrients, and colonization (Hojo et al., 2007; Mehling \& Busjahn, 2013); production of antimicrobial metabolites including the synthesis of bacteriocins, hydrogen peroxide $\left(\mathrm{H}_{2} \mathrm{O}_{2}\right)$, and organic acids such as lactic acid responsible for the acidification of the environment (Madureira et al., 2013; Messaoudi et al., 2013; Tomás et al., 2003); promotion of innate 
and adaptive immune responses (Ganguli et al., 2013; Yan \& Polk, 2011); and many other unknown modes of action.

These mechanisms lead to the modulation of the microbiota and/or inhibition of colonization by potential pathogens, and bacterial translocation across the intestinal wall (Eizaguirre et al., 2011; Wine et al., 2009; Wong et al., 2013).

A minority of bacterial species meet the definition of a probiotic microorganism, but among them are those of the genera Lactobacillus and Bifidobacterium, commonly found in the human intestine and widely used in functional foods and dietary supplements (Bermudez-Brito et al., 2012; Howarth \& Wang, 2013; Wohlgemuth et al., 2010).

These probiotic bacteria may contribute to the human health in various ways including xenobiotic detoxification, biosynthesis of vitamin $\mathrm{K}$, metabolic effects of the fermentation of nondigestible fibers (Resta, 2009), effect on gastrointestinal transit on intestinal peristalsis (Matsumoto et al., 2012), competition with pathogenic microorganisms, and modulation of the immune response.

Moreover, Lactococcus, Streptococcus, Enterococcus, nonpathogenic strains of Escherichia coli, and certain bacilli and yeast strains such as Saccharomyces boulardii can also have probiotic activity; thus, they are considered probiotic-like microorganism (Howarth \& Wang, 2013; Iannitti \& Palmieri, 2010; Magalhães et al., 2011a). They are different from probiotics in that they are not found in the gastrointestinal tract of the host (Magalhães et al., 2011a).

Foods presenting these microorganisms may be considered functional foods, i.e., besides nourishing the body, these products have biologically active components that contribute to the maintenance of good health and wellness, while reducing the risk of diseases (Mohammadi \& Mortazavian, 2011; Saad et al., 2013).

Dairy products, especially fermented products, are the main and most popular vehicles of probiotics due to their compatibility with probiotic microorganisms, pleasant sensory profile, and high consumption around the world (Mohammadi \& Mortazavian, 2011).

\subsection{Kefir}

Kefir, a product with probiotic action that deserves special attention, is a fermented beverage originating from the Caucasus mountains (Grishina et al., 2011) which provides natural probiotic microorganisms in large amount, especially Lactobacillus acidophilus, Bifidobacterium bifidum, lactic acid bacteria, and yeasts (Guzel-Seydim et al., 2011).

Traditionally, kefir is produced by inoculating kefir grains in milk for 18 to $24 \mathrm{~h}$ at a temperature of 20 to $25^{\circ} \mathrm{C}$ (Leite et al., 2013; Sarkar, 2008). At the end of the fermentation process, the kefir grains are recovered and reused, a step which is different from those in the production of other fermented milk products. Moreover, kefir does not result from the metabolic activity of a single or a few microbial species (Guzel-Seydim et al., 2011; Leite et al., 2013).
The fermentation agent of kefir known as the "kefir grain" is a gelatinous mass of protein and polysaccharide structure containing a variety of species of lactic acid bacteria, acetic acid bacteria, and yeasts, which make up a natural microbial ecosystem (Farnworth, 2005; Guzel-Seydim et al., 2011; Montanuci et al., 2012; Sarkar, 2008). Due to the large quantity and complex nature of the associations between the species involved, the microflora of kefir grains has not been fully elucidated yet (Pogačić et al., 2013).

Kefir has a distinct flavor due to the presence of various compounds produced during the fermentation process (Farnworth, 2005). Lactic acid is the major metabolite produced; other important metabolites produced are carbon dioxide and ethanol at low concentrations and flavor components, such as acetaldehyde and acetoin (Guzel-Seydim et al., 2011; Pogačić et al., 2013); bioactive peptides, vitamins, exopolysaccharides, and bacteriocins (Bergmann et al., 2010; Pogačić et al., 2013). These compounds can act independently or in combination to provide the many beneficial health effects attributed to the consumption of kefir (Farnworth, 2005).

\subsection{Benefits of kefir}

The name kefir is derived from the Turkish word keyif meaning "good food". In addition to this designation, kefir is also known by several other names, such as kefer, kefyr, kephir, kepi, kiaphur, kipi, and knapon (Yerlikaya, 2014).

Traditionally consumed in Eastern European countries, Russia, and Southeast Asia, kefir has also become popular in many countries due to its probiotic activity, unique sensory characteristics, and nutritional and therapeutic properties (Leite et al., 2013).

Among the health benefits associated with kefir are: antimicrobial property and cicatrizing activity (Rodrigues et al., 2005), antimutagenic and antioxidant effect (Liu et al., 2005), hypocholesterolemic properties (Huang et al., 2013), betagalactosidase activity (Leite et al., 2013), anti-allergenic properties, anti-inflammatory activity, and stimulation of the immune system (Lee et al., 2007; Vinderola et al., 2006).

\subsection{Development of new probiotic products}

There is a growing trend for the consumption of healthy and attractive foods by many segments of the population that increasingly seek pleasure of eating combined with health benefits and life quality. Accordingly, various dairy products with probiotic activity, especially fermented products, have been developed (Komatsu et al., 2008; Mohammadi \& Mortazavian, 2011).

Yogurt is perhaps the most common and familiar fermented product to consumers in different countries; kefir, however, is less well-known, but it has bioactive compounds that result in its unique health benefits (Farnworth, 2005).

Based on this information, the present study was conducted to develop a functional labneh, made from skim and whole milk, with probiotic activity using kefir as the fermenting agent, and to evaluate its acceptance by sensory analysis. 


\section{Materials and methods}

\subsection{Origin of kefir grains}

The kefir grains used in this study were obtained in the city of Viçosa, Minas Gerais, Brazil, and were of artisanal origin.

\subsection{Production of kefir}

Kefir grains were inoculated into different types of fluid pasteurized milk (whole and skimmed milk, with $3.0 \%$ and $0.5 \%$ of total fat, respectively), previously heat treated at $28^{\circ} \mathrm{C}$. The total amount of $5 \%$ of grains were used for fermentation, a percentage considered ideal for adequate production of ethanol and volatile acids (Sarkar, 2008). The inoculate was maintained at $28{ }^{\circ} \mathrm{C} \pm 2{ }^{\circ} \mathrm{C}$, room temperature, for 24 hours without agitation (Santos et al., 2013). At the end of this process, the grains were recovered using a sieve, washed with distilled water, and used for a subsequent fermentation run in another nutrient substrate. This process was performed three consecutive times for activation of the grains and to ensure equilibrium of the microbiota (Santos et al., 2013). At the end of this stage, the kefir obtained was separated for use in later stages of the pilot study in physicochemical analyses and development and production of labneh.

\subsection{Pilot study: physicochemical analysis of the kefir}

Labneh was initially prepared in a pilot study to identify the fermentation time that did not exceed the acidity of $1.0 \mathrm{~g}$ of lactic acid per $100 \mathrm{~g}$ of the product, as recommended for this type of fermented milk (Brasil, 2007).

Acidity was determined by titrating $10 \mathrm{~mL}$ of kefir with $0.1 \mathrm{~N}$ of $\mathrm{NaOH}$ and $1 \%$ phenolphthalein (Instituto Adolfo Lutz, 2008) for kefir prepared with different fermentation times.

\subsection{Labneh preparation}

Labneh preparation from skimmed and whole milk was performed experimentally, as shown in Figure 1.
Skimmed and whole labneh were supplemented with previously ground dried tomatoes $(30 \%, \mathrm{w} / \mathrm{w})$, garlic $(0.2 \%, \mathrm{w} / \mathrm{w})$, and oregano $(0.4 \%, \mathrm{w} / \mathrm{w})$. The ingredients were mixed until homogenization of the product, and the mixture was then stored refrigerated overnight until sensory analysis.

\subsection{Sensory analysis}

Sensory analysis was performed in individual partitioned booths with neutral colored walls under white lightening.

Untrained panelists, chosen by convenience, received randomly 2 coded samples (each containing approximately $15 \mathrm{~g}$ of skimmed and whole labneh/portion), water to rinse their mouth, the evaluation questionnaire, and a pencil and an eraser. The parameters evaluated were appearance, texture, flavor, and overall impression. A structured 9-point hedonic scale ranging from 1 (extremely disliked) to 9 (extremely liked) was used in the preference tests (Peryam \& Pilgrim, 1957). The panelists were also asked about their intent to purchase the products.

Criteria for inclusion in the study were: being 18 or older, agreed to voluntarily participate in the study, and signed the Informed Consent Form. Those who had any kind of allergy or intolerance to any component of the product (milk, dried tomatoes and spices) were not allowed to participate, and the potential participants were informed about this restriction.

The present study was approved by the Ethics Committee on Human Research of the Federal University of Viçosa (case number 339.319), on July 5, 2013, as required by Resolution $466 / 12$, which deals with ethics in research involving humans (Brasil, 2012).

\subsection{Statistical analysis}

Samples characterization and purchase intent were expressed as mean \pm standard deviation or frequency (\%). The paired t-test was used to compare the statistically significant differences between the means of the samples (Lawless \& Heymann, 2010), with the significance level of 5\%. The software

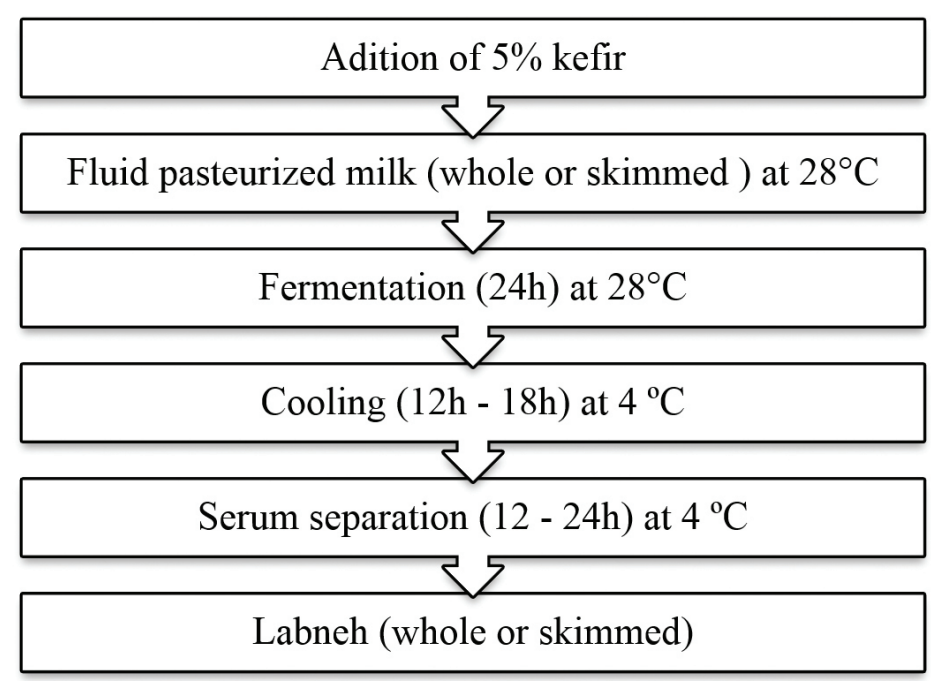

Figure 1. Flowchart of kefir labneh preparation. 
SPSS (Statistical Package for the Social Sciences version 20.0 for Windows) was used in the statistical analysis.

\section{Results and discussion}

\subsection{Physicochemical analysis of kefir}

In the pilot study, there was an increase in acidity during the fermentation of kefir (Figure 2). This result is of great importance because lactic acid is a fermentation product that not only adds pleasant taste to kefir but also inhibits the growth of undesirable microorganisms or pathogens due to increased acidity of the kefir (Magalhães et al., 2011b).

According to the standards of identity and quality of fermented milks, the lactic acid concentration in kefir should be less than $1.0 \mathrm{~g}$ of lactic acid per $100 \mathrm{~g}$ of the final product (Brasil, 2007). The values found after 24 hours of fermentation are within the range established: whole and skimmed kefir showed maximum acidity values of 0.75 and $0.91 \%$ lactic acid, respectively.

\subsection{Labneh}

Preparation of labneh from kefir can be easily done at home. However, it showed low yield due to the syneresis process in which there was a loss of approximately $60 \%$ and $75 \%$ of the initial volume in the kefir made from whole and skimmed milk, respectively.

At the industrial scale, this procedure can be performed using modern techniques of centrifugation, recombination technology, and ultrafiltration methods (Kaaki et al., 2012), minimizing protein losses from the product (Santos et al., 2012).

The price of $30 \mathrm{~g}$ of the product ranges from US\$ 0.31 to US $\$ 0.23$ for the skimmed and whole versions both with dried tomatoes and spices, respectively, considering the price of the ingredients purchased from local supermarkets.

\subsection{Characterization of the judges}

A total of 70 untrained panelists (52 women $(74.3 \%$ ) and 18 men $(25.7 \%)$ ) participated in the study. The age of the participants ranged from 18 to 65 years, with an average of $26.33 \pm 9.45$ years. Regarding their level of education, only one individual (1.4\%) reported having only the elementary level of education, 41 (58.6\%) completed high school, and 28 (40\%) completed higher education.

\subsection{Acceptance test}

The panelists gave higher scores to the whole labneh than to skimmed labneh for appearance (7.87 vs 7.43 ; $\mathrm{p}<0.001)$, flavor (7.86 vs. $7.13 ; \mathrm{p}=0.001)$, texture ( 7.86 vs $7.46 ; \mathrm{p}=0.001)$, and overall impression (7.99 vs 7.37; $\mathrm{p}<0.001$ ). Differences in the average scores were considered significant.

Greater frequency of scores above 5, corresponding to the term "indifferent", for the attributes (appearance, texture, flavor, and overall impression) was observed for the whole labneh.
Additionally, both products received a high percentage of scores above 5 for all attributes evaluated (Figure 3).

As for purchase intent, if the products were marketed, 62 judges $(88.6 \%)$ said they would buy the whole labneh, and $36(51.4 \%)$ would buy the skimmed labneh. Approximately $41.4 \%$ of the judges $(n=29)$ would buy both products, and only $1.4 \%(n=1)$ of the participants said that they would not buy either product.

It may be considered that both products were well accepted by the judges, and the whole labneh was the product of greater acceptance, with higher score in all attributes evaluated.

The taste of the product appears to be related to the lower score attributed to skimmed labneh. This version had a more pronounced acidity, resulting from the production of lactic acid during fermentation of the product, as remarked by the judges

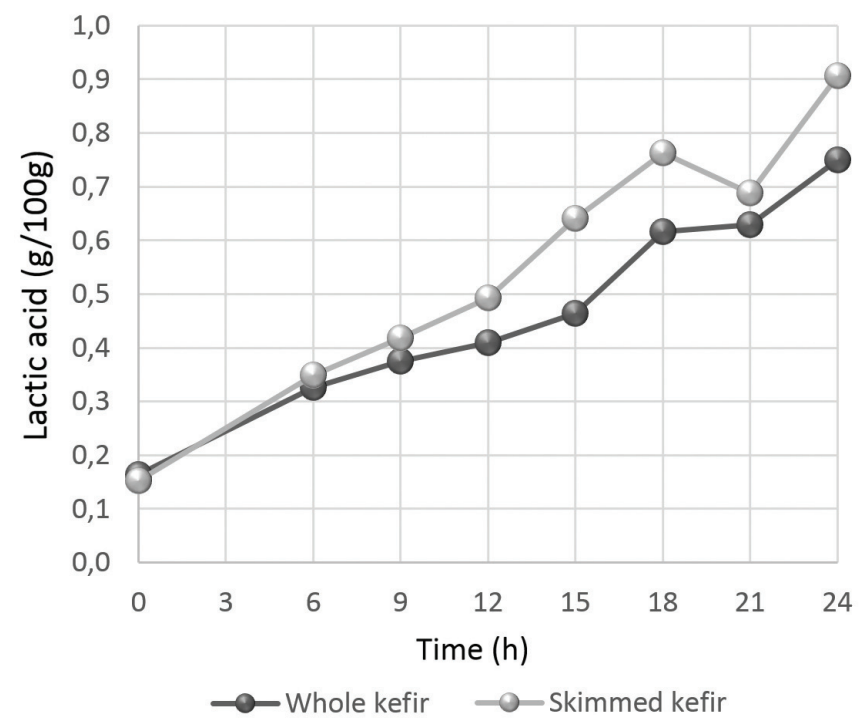

Figure 2. Production of lactic acid during fermentation of kefir at $28^{\circ} \mathrm{C}$.

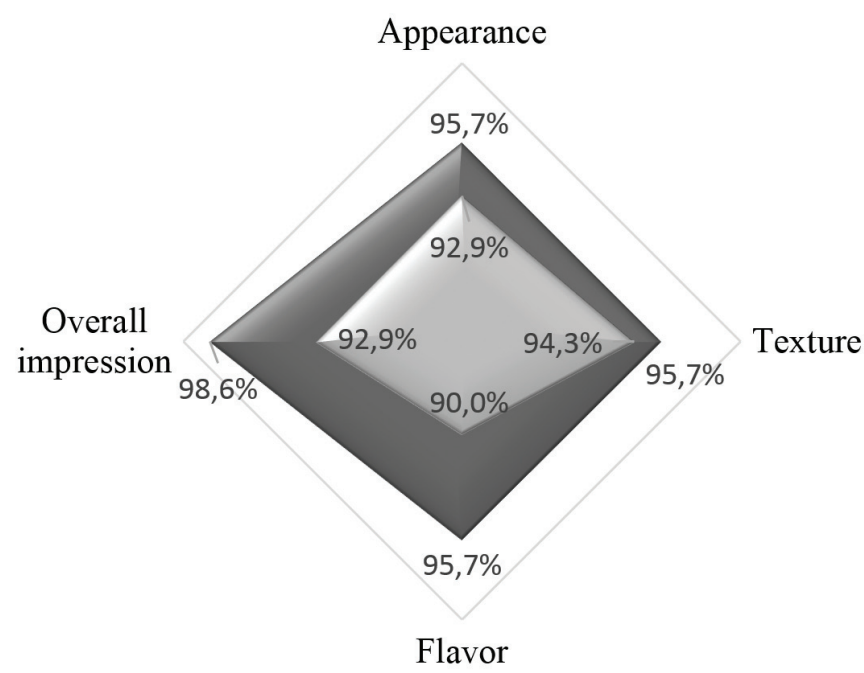

Whole Labneh $\square$ Skimmed Labneh

Figure 3. Frequency of ratings above "Indifferent" for Labneh samples. 
in the evaluation sheets. In another sensory analysis of cocoabased kefir, the samples with lower acidity also showed better acceptance (Puerari et al., 2012).

A similar study of comparative sensory evaluation of buffalo milk yogurt indicated preference for whole milk yogurt (3.0\% fat) over skimmed milk yogurt (0.5\%) (Cunha Neto et al., 2005). Moreover, a comparison of different types of commercial labneh in Lebanon, showed higher rating for whole labneh in terms of appearance, texture, flavor, and overall impression with decreased acceptability as the fat percentage was reduced (Kaaki et al., 2012). This fact reinforces the need for alternatives to improve acceptance of the low-fat versions of these products.

Daily consumption of probiotics containing 1-10 billion CFU/day (Guarner et al., 2012) is recommended to confer the associated health benefits. Thus, quantification of microorganisms present in the final product and the analyses of microbiological viability, shelf life, and nutritional composition are essential for an effective guidance on its consumption and commercialization.

\section{Conclusions}

Considering the high acceptability of the elaborated labneh, it can be inferred that kefir can be used for its preparation. It is a product with interesting probiotic activity for artisan preparation since it is a low-cost product and is relatively easy to prepare. Therefore, its use should be recommended to encourage consumption, especially among the low-income population with little access to products with probiotic activity. The analysis of microbiological content and viability, nutritional composition, and determination of the shelf life and also improvement of the acceptability of a low-fat version of the product are topics for future studies.

\section{Acknowledgement}

The authors thank Isabel Irani Campos do Carmo and Maria Inês de Souza Dantas for technical assistance, and are grateful to the participant judges and to the faculty members of the Department of Nutrition and Health, Federal University of Viçosa (Departamento de Nutrição e Saúde, Universidade Federal de Viçosa).

\section{References}

Abd El-Salam, M. H., Hippen, A. R., El-Shafie, K., Assem, F. M., Abbas, H., Abd El-Aziz, M., Sharaf, O., \& El-Aassar, M. (2011). Preparation and properties of probiotic concentrated yoghurt (labneh) fortified with conjugated linoleic acid. International Journal of Food Science \& Technology, 46(10), 2103-2110. http://dx.doi.org/10.1111/j.13652621.2011.02722.x.

Balgir, P. P., Kaur, B., Kaur, T., Daroch, N., \& Kaur, G. (2013). In vitro and in vivo survival and colonic adhesion of Pediococcus acidilactici MTCC5101 in human gut. BioMed Research International, 2013, 583850. http://dx.doi.org/10.1155/2013/583850. PMid:24175293

Bergmann, R. S. D. O., Pereira, M. A., Veiga, S. M. O. M., Schneedorf, J. M., Oliveira, N. M. S., \& Fiorini, J. E. (2010). Microbial profile of a kefir sample preparations: grains in natura and lyophilized and fermented suspension. Food Science and Technology, 30(4), 1022-1026. http://dx.doi.org/10.1590/S0101-20612010000400029.

Bermudez-Brito, M., Plaza-Díaz, J., Muñoz-Quezada, S., GómezLlorente, C., \& Gil, A. (2012). Probiotic mechanisms of action. Annals of Nutrition \& Metabolism, 61(2), 160-174. http://dx.doi. org/10.1159/000342079. PMid:23037511

Brasil, Ministério da Agricultura e da Pecuária e Abastecimento MAPA. (2007). Regulamento Técnico de Identidade e Qualidade de Leites Fermentados (Instrução Normativa $n^{\circ} 46$, de 23 de outubro de 2007). Diário Oficial da União.

Brasil, Conselho Nacional de Saúde - CNS. (2012). Diretrizes e normas regulamentadoras de pesquisas envolvendo seres humanos (Resoluçao $n^{\circ} 466$, de 12 de dezembro de 2012). Diário Oficial da União.

Cunha Neto, O. C., Oliveira, C. A. F., Hotta, R. M., \& Sobral, P. J. A. (2005). Avaliação físico-química e sensorial do iogurte natural produzido com leite de búfala contendo diferentes níveis de gordura. Food Science and Technology, 25(3), 448-453. http://dx.doi. org/10.1590/S0101-20612005000300010.

Eizaguirre, I., Aldazabal, P., Urkia, N. G., Asensio, A., \& Arenzxana, J. M. (2011). Escherichia coli translocation in experimental short bowel syndrome: probiotic supplementation and detection by polymerase chain reaction. Pediatric Surgery International, 27(12), 1301-1305. http://dx.doi.org/10.1007/s00383-011-2943-z. PMid:21748652

Farnworth, E. R. (2005). Kefir: a complex probiotic. Food Science and Technology Bulletin: Functional Foods, 2(1), 1-17.

Food and Agriculture Organization of the United Nations, World Health Organization - FAO/WHO. (2006). Probiotics in foods: health and nutritional properties and guidelines for evaluation (FAO Food and Nutrition Paper, No. 85, pp. 62). Rome.

Ganguli, K., Meng, D., Rautava, S., Lu, L., Walker, W. A., \& Nanthakumar, N. (2013). Probiotics prevent necrotizing enterocolitis by modulating enterocyte genes that regulate innate immune-mediated inflammation. American Journal of Physiology: Gastrointestinal and Liver Physiology, 304(2), G132-G141. http://dx.doi.org/10.1152/ ajpgi.00142.2012. PMid:23139215

Grishina, A., Kulikova, I., Alieva, L., Dodson, A., Rowland, I., \& Jin, J. (2011). Antigenotoxic effect of kefir and ayran supernatants on fecal water-induced DNA damage in human colon cells. Nutrition and Cancer, 63(1), 73-79. PMid:21161824.

Guarner, F., Khan, A. G., Garisch, J., Eliakim, R., Gangl, A., Thomson, A., Krabshuis, J., Lemair, T., Kaufmann, P., de Paula, J. A., Fedorak, R., Shanahan, F., Sanders, M. E., Szajewska, H., Ramakrishna, B. S., Karakan, T., \& Kim, N., and the World Gastroenterology Organization (2012). World Gastroenterology Organisation Global Guidelines: probiotics and prebiotics October 2011. Journal of Clinical Gastroenterology, 46(6), 468-481. http://dx.doi.org/10.1097/ MCG.0b013e3182549092. PMid:22688142

Guzel-Seydim, Z. B., Kok-Tas, T., Greene, A. K., \& Seydim, A. C. (2011). Review: functional properties of kefir. Critical Reviews in Food Science and Nutrition, 51(3), 261-268. http://dx.doi. org/10.1080/10408390903579029. PMid:21390946

Hojo, K., Nagaoka, S., Murata, S., Taketomo, N., Ohshima, T., \& Maeda, N. (2007). Reduction of vitamin K concentration by salivary Bifidobacterium strains and their possible nutritional competition with Porphyromonas gingivalis. Journal of Applied Microbiology, 103(5), 1969-1974. http://dx.doi.org/10.1111/j.13652672.2007.03436.x. PMid:17953607

Howarth, G. S., \& Wang, H. (2013). Role of endogenous microbiota, probiotics and their biological products in human health. Nutrients, 5(1), 58-81. http://dx.doi.org/10.3390/nu5010058. PMid:23306189 
Huang, Y., Wu, F., Wang, X., Sui, Y., Yang, L., \& Wang, J. (2013). Characterization of Lactobacillus plantarum Lp27 isolated from Tibetan kefir grains: a potential probiotic bacterium with cholesterol-lowering effects. Journal of Dairy Science, 96(5), 28162825. http://dx.doi.org/10.3168/jds.2012-6371. PMid:23498003

Iannitti, T., \& Palmieri, B. (2010). Therapeutical use of probiotic formulations in clinical practice. Clinical nutrition, 29(6), 701-725. http://dx.doi.org/10.1016/j.clnu.2010.05.004. PMid:20576332

Instituto Adolfo Lutz - IAL. (2008). Leites e derivados. In O. Zenebon, N. S. Pascuet \& P. Tiglea (Eds.), Métodos físico-químicos para análise de alimentos (4. ed., pp. 823-881). São Paulo.

Kaaki, D., Kebbe Baghdadi, O., Najm, N. E., \& Olabi, A. (2012). Preference mapping of commercial Labneh (strained yogurt) products in the Lebanese market. Journal of Dairy Science, 95(2), 521-532. http://dx.doi.org/10.3168/jds.2011-4409. PMid:22281316

Komatsu, T. R., Buriti, F. C. A., \& Saad, S. M. I. (2008). Inovação, persistência e criatividade superando barreiras no desenvolvimento de alimentos probióticos. Revista Brasileira de Ciências Farmacêuticas, 44(3), 329-347.

Lara-Villoslada, F., Sierra, S., Boza, J., Xaus, J., \& Olivares, M. (2007). [Beneficial effects of consumption of a dairy product containing two probiotic strains, Lactobacillus coryniformis CECT5711 and Lactobacillus gasseri CECT5714 in healthy children]. Nutrición Hospitalaria, 22(4), 496-502. PMid:17650892.

Lawless, H. T., \& Heymann, H. (2010). Sensory evaluation of food (2nd ed., pp. 473-478). New York: Springer. http://dx.doi. org/10.1007/978-1-4419-6488-5.

Lee, M.-Y., Ahn, K. S., Kwon, O. K., Kim, M. J., Kim, M. K., Lee, I. Y., Oh, S. R., \& Lee, H. K. (2007). Anti-inflammatory and antiallergic effects of kefir in a mouse asthma model. Immunobiology, 212(8), 647-654. http://dx.doi.org/10.1016/j.imbio.2007.05.004. PMid:17869642

Leite, A. M. O., Miguel, M. A., Peixoto, R. S., Rosado, A. S., Silva, J. T., \& Paschoalin, V. M. (2013). Microbiological, technological and therapeutic properties of kefir: a natural probiotic beverage. Brazilian Journal of Microbiology, 44(2), 341-349. http://dx.doi. org/10.1590/S1517-83822013000200001. PMid:24294220

Liu, J.-R., Chen, M.-J., \& Lin, C.-W. (2005). Antimutagenic and antioxidant properties of milk-kefir and soymilk-kefir. Journal of Agricultural and Food Chemistry, 53(7), 2467-2474. http://dx.doi. org/10.1021/jf048934k. PMid:15796581

Madureira, A. R., Soares, J. C., Amorim, M., Tavares, T., Gomes, A. M., Pintado, M. M., \& Malcata, F. X. (2013). Bioactivity of probiotic whey cheese: characterization of the content of peptides and organic acids. Journal of the Science of Food and Agriculture, 93(6), 14581465. http://dx.doi.org/10.1002/jsfa.5915. PMid:23400948

Magalhães, K. T., Pereira, G. V. M., Campos, C. R., Dragone, G., \& Schwan, R. F. (2011a). Brazilian kefir: structure, microbial communities and chemical composition. Brazilian Journal of Microbiology, 42(2), 693-702. http://dx.doi.org/10.1590/S151783822011000200034. PMid:24031681

Magalhães, M. S., Salminen, S., Ferreira, C., \& Tommola, J. (2011b). Probiotics. In M. S. Magalhães, S. Salminen, C. Ferreira \& J. Tommola (Eds.), Terminology: functional foods, probiotics, prebiotics, synbiotics, health claims, sensory evaluation of foods, molecular gastronomy (pp. 33-47). Turku: Univeristy of Turku/Functional Foods Forum.

Matsumoto, M., Ishige, A., Yazawa, Y., Kondo, M., Muramatsu, K., \& Watanabe, K. (2012). Promotion of intestinal peristalsis by Bifidobacterium spp. capable of hydrolysing sennosides in mice.
PLoS ONE, 7(2), e31700. http://dx.doi.org/10.1371/journal. pone.0031700. PMid:22384059

Mehling, H., \& Busjahn, A. (2013). Non-viable Lactobacillus reuteri DSMZ 17648 (PylopassTM) as a new approach to Helicobacter pylori control in humans. Nutrients, 5(8), 3062-3073.

Messaoudi, S., Manai, M., Kergourlay, G., Prévost, H., Connil, N., Chobert, J. M., \& Dousset, X. (2013). Lactobacillus salivarius: bacteriocin and probiotic activity. Food Microbiology, 36(2), 296304. http://dx.doi.org/10.1016/j.fm.2013.05.010. PMid:24010610

Mohammadi, R., \& Mortazavian, A. M. (2011). Review article: technological aspects of prebiotics in probiotic fermented milks. Food Reviews International, 27(2), 192-212. http://dx.doi.org/10.1 080/87559129.2010.535235.

Montanuci, F. D., Pimentel, T. C., Garcia, S., \& Prudencio, S. H. (2012). Effect of starter culture and inulin addition on microbial viability, texture, and chemical characteristics of whole or skim milk Kefir. Food Science and Technology, 32(4), 580-865.

Nsabimana, C., Jiang, B., \& Kossah, R. (2005). Manufacturing, properties and shelf life of labneh: a review. International Journal of Dairy Technology, 58(3), 129-137. http://dx.doi.org/10.1111/j.14710307.2005.00205.x.

Özer, B., \& Robinson, R. (1999). The behaviour of starter cultures in concentrated yoghurt (labneh) produced by different techniques. LWT - Food Science and Technology, 32(7), 391-395. http://dx.doi. org/10.1006/fstl.1999.0566.

Persborn, M., Gerritsen, J., Wallon, C., Carlsson, A., Akkermans, L. M., \& Söderholm, J. D. (2013). The effects of probiotics on barrier function and mucosal pouch microbiota during maintenance treatment for severe pouchitis in patients with ulcerative colitis. Alimentary Pharmacology \& Therapeutics, 38(7), 772-783. http:// dx.doi.org/10.1111/apt.12451. PMid:23957603

Peryam, D. R., \& Pilgrim, F. J. (1957). Hedonic scale method of measuring food preferences. Food Technology, 11, 9-14.

Pogačić, T., Šinko, S., Zamberlin, Š., \& Samaržija, D. (2013). Microbiota of kefir grains. Mljekarstvo, 63(1), 3-14.

Puerari, C., Magalhães, K. T., \& Schwan, R. F. (2012). New cocoa pulpbased kefir beverages: Microbiological, chemical composition and sensory analysis. Food Research International, 48(2), 634-640. http:// dx.doi.org/10.1016/j.foodres.2012.06.005.

Ramos, T. M., Gajo, A. A., Pinto, S. M., Abreu, L. R., \& Pinheiro, A. C. (2009). Perfil de textura de Labneh (iogurte Grego). Revista do Instituto de Laticínios Cândido Tostes, 64(369), 8-12.

Resta, S. C. (2009). Effects of probiotics and commensals on intestinal epithelial physiology: implications for nutrient handling. The Journal of Physiology, 587(17), 4169-4174. http://dx.doi.org/10.1113/ jphysiol.2009.176370. PMid:19596893

Rodrigues, K. L., Caputo, L. R., Carvalho, J. C., Evangelista, J., \& Schneedorf, J. M. (2005). Antimicrobial and healing activity of kefir and kefiran extract. International Journal of Antimicrobial Agents, 25(5), 404-408. http://dx.doi.org/10.1016/j.ijantimicag.2004.09.020. PMid:15848295

Saad, N., Delattre, C., Urdaci, M., Schmitter, J. M., \& Bressollier, P. (2013). An overview of the last advances in probiotic and prebiotic field. LWT - Food Science and Technology, 50(1), 1-16. http://dx.doi. org/10.1016/j.lwt.2012.05.014.

Santos, J. P. V., Araújo, T. F., Ferreira, C. L. L. F., \& Goulart, S. M. (2013). Evaluation of antagonistic activity of milk fermented with kefir grains of different origins. Brazilian Archives of Biology and Technology, 56(5), 823-827. http://dx.doi.org/10.1590/S151689132013000500014 . 
Santos, T. S. S., Martins, J. F. L., Rocha, D. M. U. P., \& Moreira, A. V. B. (2012). "Petit suisse" cheese from kefir: an alternative dessert with microorganisms of probiotic activity. Food Science and Technology, 32(3), 485-491.

Sarkar, S. (2008). Biotechnological innovations in kefir production: a review. British Food Journal, 110(3), 283-295. http://dx.doi. org/10.1108/00070700810858691.

Tomás, M. S. J., Bru, E., \& Nader-Macías, M. E. (2003). Comparison of the growth and hydrogen peroxide production by vaginal probiotic lactobacilli under different culture conditions. American Journal of Obstetrics and Gynecology, 188(1), 35-44. http://dx.doi.org/10.1067/ mob.2003.123. PMid:12548193

Vinderola, G., Perdigón, G., Duarte, J., Farnworth, E., \& Matar, C. (2006). Effects of the oral administration of the products derived from milk fermentation by kefir microflora on immune stimulation. The Journal of Dairy Research, 73(4), 472-479. http://dx.doi. org/10.1017/S002202990600197X. PMid:16827951

Wine, E., Gareau, M. G., Johnson-Henry, K., \& Sherman, P. M. (2009). Strain-specific probiotic (Lactobacillus helveticus) inhibition of Campylobacter jejuni invasion of human intestinal epithelial cells. FEMS Microbiology Letters, 300(1), 146-152. http://dx.doi. org/10.1111/j.1574-6968.2009.01781.x. PMid:19765084
Wohlgemuth, S., Loh, G., \& Blaut, M. (2010). Recent developments and perspectives in the investigation of probiotic effects. International Journal of Medical Microbiology, 300(1), 3-10. http://dx.doi. org/10.1016/j.ijmm.2009.08.003. PMid:19783478

Wong, S.-S., Quan Toh, Z., Dunne, E. M., Mulholland, E. K., Tang, M. L., Robins-Browne, R. M., Licciardi, P. V., \& Satzke, C. (2013). Inhibition of Streptococcus pneumoniae adherence to human epithelial cells in vitro by the probiotic Lactobacillus rhamnosus GG. BMC Research Notes, 6(1), 135. http://dx.doi.org/10.1186/17560500-6-135. PMid:23561014

Yan, F., \& Polk, D. B. (2011). Probiotics and immune health. Current Opinion in Gastroenterology, 27(6), 496-501. http://dx.doi. org/10.1097/MOG.0b013e32834baa4d. PMid:21897224

Yerlikaya, O. (2014). Starter cultures used in probiotic dairy product preparation and popular probiotic dairy drinks. Food Science and Technology, 34(2), 221-229.

Zeng, J., Li, Y. Q., Zuo, X. L., Zhen, Y. B., Yang, J., \& Liu, C. H. (2008). Clinical trial: effect of active lactic acid bacteria on mucosal barrier function in patients with diarrhoea-predominant irritable bowel syndrome. Alimentary Pharmacology \& Therapeutics, 28(8), 994-1002. http://dx.doi.org/10.1111/j.1365-2036.2008.03818.x. PMid:18671775 